\title{
Philadelphia chromosome-positive B-cell acute lymphoblastic leukemia with e1a3 $B C R-A B L 1$ transcript in a Nigerian with sickle cell anemia: a case report
}

\author{
Ibrahim O. Ahmed ${ }^{1}$, Lauretta O. Ochogwu' ${ }^{1}$, Temilola O. Owojuyigbe ${ }^{1,2^{*}} \mathbb{D}$, Norah O. Akinola ${ }^{1,2}$ and
} Muheez A. Durosinmi ${ }^{1,2}$

\begin{abstract}
Background: The occurrence of acute leukemia in patients with sickle cell anemia is uncommon. The Philadelphia chromosome is the hallmark of chronic myeloid leukemia. However, it may also be associated with acute lymphoblastic leukemia and acute myeloblastic leukemia. The common BCR-ABL1 transcripts seen in acute lymphoblastic leukemia are e1a2, e13a2, and e14a2, while other transcripts such as e1a3, e13a3, and e6a2 occur rarely. This report describes the presentation, management, and outcome of the occurrence of B-cell acute lymphoblastic leukemia with the rare e1a3 BCR-ABL1 transcript in a patient with sickle cell anemia.

Case presentation: A 19-year-old male Nigerian, a known sickle cell anemia patient was admitted on account of severe vaso-occlusive crisis. Examination revealed fever, palor, and jaundice. Full blood count showed anemia and leukocytosis. Peripheral blood and bone marrow smears revealed numerous large and small lymphoblasts in keeping with the L2 subtype of acute lymphoblastic leukemia based on the French-American-British classification. Further evaluation was in keeping with a diagnosis of $B C R$ - $A B L 1$-positive mature B-cell acute lymphoblastic leukemia associated with the rare e1a3 transcript. He was commenced simultaneously on induction chemotherapy and Imatinib while being prepared for allogeneic stem cell transplantation. However, he died six months after diagnosis from meningoencephalitis.
\end{abstract}

Conclusion: The occurrence of acute lymphoblastic leukemia with a rare $B C R-A B L 1$ e1a3 transcript in association with sickle cell anemia is uncommon and associated with poor prognosis.

Keywords: Acute lymphoblastic leukemia, Sickle cell anemia, BCR-ABL1, e1a3, Case report

\section{Introduction}

Sickle cell anemia (SCA) is the most prevalent hemoglobinopathy worldwide and occurs due to the homozygous inheritance of hemoglobin $\mathrm{S}(\mathrm{HbS})$ [1]. Hemoglobin $\mathrm{S}$ is an abnormal form of adult hemoglobin ( $\mathrm{HbA})$ that

*Correspondence: temilolly@yahoo.com

1 Department of Haematology and Blood Transfusion, Obafemi Awolowo University Teaching Hospitals Complex (OAUTHC), Ile-Ife, Nigeria

Full list of author information is available at the end of the article is produced due to a point mutation in the sixth codon of the beta globin gene (GAG to GTG) resulting in the replacement of the hydrophilic amino acid glutamate by the hydrophobic amino acid valine in the sixth position of the $\mathrm{Hb}$ beta chain. The abnormal $\mathrm{HbS}$ polymerizes when deoxygenated and induces sickling of red blood cells (RBCs). The clinical features include chronic hemolysis, anemia, and periodic episodes of acute pain termed vaso-occlusive crisis (VOC) [2]. The occurrence of acute leukemia in individuals with SCA is rare $[2,3]$. This has original author(s) and the source, provide a link to the Creative Commons licence, and indicate if changes were made. The images or other third party material in this article are included in the article's Creative Commons licence, unless indicated otherwise in a credit line to the material. If material is not included in the article's Creative Commons licence and your intended use is not permitted by statutory regulation or exceeds the permitted use, you will need to obtain permission directly from the copyright holder. To view a copy of this licence, visit http://creativecommons.org/licenses/by/4.0/. The Creative Commons Public Domain Dedication waiver (http://creativeco mmons.org/publicdomain/zero/1.0/) applies to the data made available in this article, unless otherwise stated in a credit line to the data. 
been attributed to the reduced life expectancy associated with SCA. The Philadelphia chromosome $(\mathrm{Ph})$ is the shortened chromosome 22 that results from the reciprocal translocation between the long arms of chromosomes 9 and 22, that is, (t9;22)(q34:q11) with the formation of a novel fusion gene $B C R-A B L 1$ that drives oncogenesis due to increased tyrosine kinase activity [4]. This acquired gene rearrangement is most classically associated with CML, but it could also be found in ALL and AML $[4,5]$. There are many variants of the $B C R-A B L 1$ fusion gene depending on the site of breakpoint in the $B C R$ gene [5]. The most common $B C R-A B L 1$ fusion transcript seen in about $70 \%$ of Ph-positive ALL is the p190 variant, which results from the rearrangement between exon 1 of $B C R$ and exon 2 of ABL1, that is, e1a2. About $30 \%$ of cases of Ph-positive ALL are associated with the $\mathrm{p} 210$ variant [that has two forms, namely e13a2 (or b2a2) and e14a2 (or b3a2)] [6]. Baccaranni et al., however, reported the occurrence of e13a2 transcript in $58.5 \%$ of 497 BCR$A B L 1$ positive ALL patients [7]. Atypical variants of the $B C R-A B L 1$ gene such as e1a3, e13a3, and e6a 2 occur rarely $[6,8]$. The presence of $B C R-A B L 1$ transcript in ALL is associated with a relatively poor prognosis, necessitating the addition of tyrosine kinase inhibitor (TKI) into the treatment regimen [7].

Philadelphia-chromosome positive $(\mathrm{Ph}+)$ acute lymphoblastic leukemia is a distinct entity that is characterized by specific genomic alterations, low sensitivity to chemotherapy, unstable responsiveness to tyrosine kinase inhibitors (TKIs), and a poor prognosis $[8,9]$.

We report a rare case of Ph-positive B-cell ALL with e1a3 $B C R-A B L 1$ transcript in a 19-year-old Nigerian with SCA.

\section{Case presentation}

A 19-year-old Nigerian, known SCA patient who was diagnosed in childhood but had been receiving care in a secondary health facility presented to the emergency room in May 2020 with generalized body pains, fever, weakness, and palpitations of four days duration. There was no history of passage of dark-colored urine, thus excluding hemolysis. The patient had never used hydroxycarbamide nor any other disease-modifying agent. He was diagnosed to have SCA at the age of 1 year during a febrile illness when a routine $\mathrm{Hb}$ electrophoresis was done. In early childhood, he had frequent episodes of VOC that required hospitalization (more than four times annually) and required numerous blood transfusions (more than three times in a year). However, in his teenage years, VOCs were said to have become less frequent (once or twice in a year) and less intense with significant reduction in hospital admission rate (once or twice in a year) and blood transfusion requirements (less than once in a year). The last episode of crises that required hospitalization (at a private hospital in Port-Harcourt, Nigeria) occurred a year prior to index presentation. The last blood transfusion was at age 15 years. He did not attend any clinic for follow-up, but presented mainly at the emergency room during crises when home treatment was not effective. He did not have splenectomy as this is not routinely done in Nigeria for patients with SCA. He was not compliant with the prescribed daily medications, which included proguanil, folic acid, vitamin B-complex, and vitamin $\mathrm{C}$. He was the last of three children in a monogamous family, in which both parents and his siblings had Hb AS phenotype.

Examination revealed a young man in painful distress with pyrexia (temperature $38.3^{\circ} \mathrm{C}$ ), palor, slight jaundice, no significant peripheral lymphadenopathy, and no pedal edema. Respiratory rate was 24 breaths/minute. Pulse was 120 beats/minute, regular, but of small volume. Blood pressure was $\frac{120}{70} \mathrm{mmHg}$, while the apex beat was palpable at the fifth left intercostal space, mid-axillary line. The first $\left(\mathrm{S}_{1}\right)$ and second $\left(\mathrm{S}_{2}\right)$ heart sounds were heard. There was no abdominal tenderness, but the liver was palpably enlarged, $4 \mathrm{~cm}$ below the right costal margin and had a span of $18 \mathrm{~cm}$. The spleen was not palpable, and the kidneys not ballotable. He had no neurological abnormality. Baseline full blood count (FBC) showed severe anemia (hemoglobin concentration $4.6 \mathrm{~g} / \mathrm{dl}$ ), leukocytosis (WBC $44.3 \times 10^{9} / \mathrm{L}$ ) and platelet count of $335.0 \times 10^{9} / \mathrm{L}$. Blood film microscopy for malaria showed trophozoites of Plasmodium falciparum. Hb electrophoresis on agarose gel with densitometric quantification (Hellabio, Thessaloniki, Greece) done at presentation revealed $\mathrm{HbS}$ 93.6\%, $\mathrm{HbF} 2.9 \%, \mathrm{HbA}_{2}$ 3.5\%. Steady-state hematocrit was unknown. An initial diagnosis of VOC with severe anemia was made. He was treated with artesunate-based antimalarial and transfused with packed cells. However, a review of the peripheral blood film showed sickled and target cells in addition to leukocytosis that consisted of heterogeneous lymphoblasts (81\%), myelocytes (2\%), neutrophils (10\%), and lymphocytes (7\%) (Fig. 1). Urine analysis was normal. Abdominal ultrasound scan showed hepatomegaly and autosplenectomy. Electrocardiogram (ECG) showed left ventricular hypertrophy (LVH), while echocardiogram (ECHO) showed LVH with normal systolic and diastolic function. Serology tests for human immunodeficiency virus (HIV), hepatitis B virus, and hepatitis $\mathrm{C}$ virus were negative. Bone marrow aspiration (BMA) revealed a hypercellular marrow with numerous heterogeneous lymphoblasts constituting about $60 \%$ of marrow nucleated cells. Flow cytometry of the peripheral blood revealed blasts that were CD20+, CD3-, CD13-, and CD33-. Multiplex reverse transcriptase polymerase chain reaction (RT-PCR) was done for $B C R-A B L 1$ 

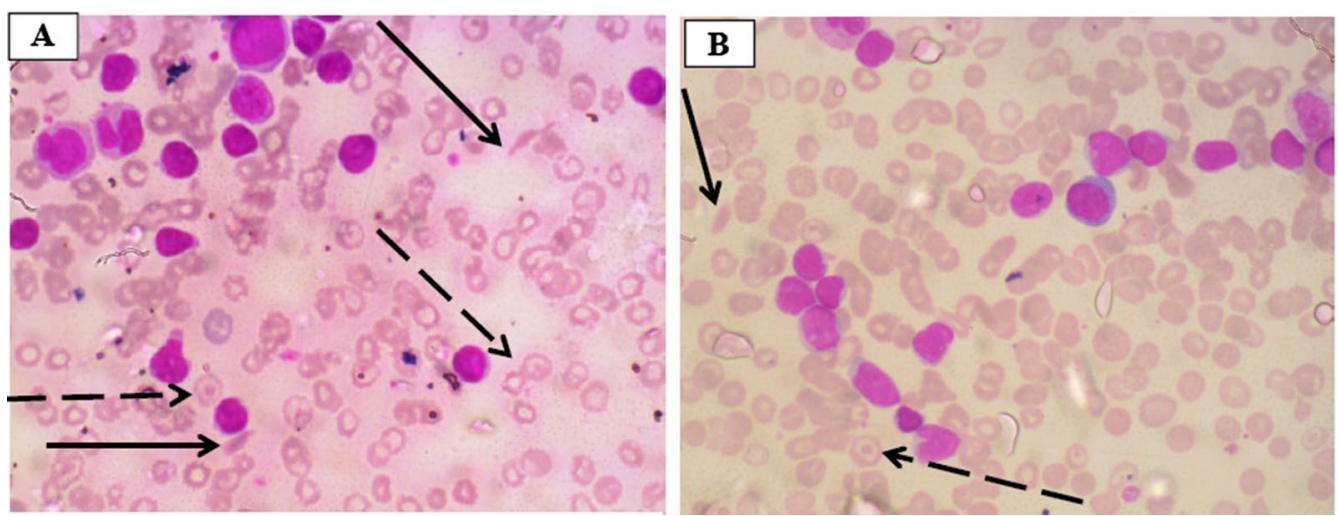

Fig. 1 Peripheral blood film of the patient. Different views of the peripheral blood film of the patient showing numerous heterogeneous lymphoblasts, sickle cells (solid arrows), and target cells (dashed arrows)

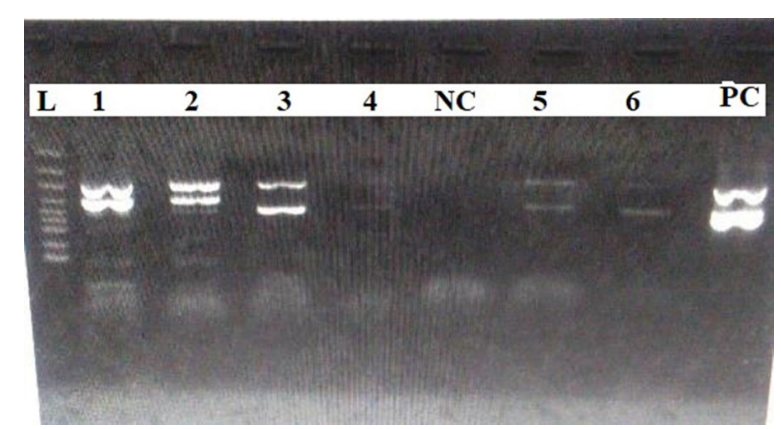

Fig. 2 Polymerase chain reaction analysis of $B C R-A B L 1$ transcripts. Lane L: DNA ladder, Lane 1: e1a3 (index patient), Lane 2: e13a2 + e14a2, Lane 3: e14a2, Lane 4: e14a2 (low value), NC: negative control, Lane 5: e14a2, Lane 6: e14a2, PC: positive control

analysis (Seeplex Leukemia BCR-ABL kit, Seegene, Seoul, Korea) and showed the presence of e1a3 transcript (Fig. 2). A diagnosis of B-lineage $B C R-A B L 1$ positive ALL in a known patient with SCA was made. Lymphoblasts were not visualized on cytospin analysis of CSF, thus excluding CNS involvement. However, he was classified as being at high risk for meningeal relapse on the basis of high WBC count $\left(\mathrm{WBC}>30.0 \times 10^{9} / \mathrm{L}\right)$, mature B-cell phenotype and $\mathrm{Ph}$ expression.He was commenced on the modified MCP 841 regimen (Table 1) $[10,11]$. This protocol included four induction cycles (1A, 2A, 2B, 1B); one cycle of consolidation and six cycles of maintenance therapy. Induction $1 \mathrm{~A}$ involved the administration of prednisolone, vincristine, L-asparaginase, and daunorubicin. He was also given three-drug intrathecal therapy (IT) [methotrexate, hydrocortisone, and cytarabine, that is, triple IT] by aseptic technique for CNS prophylaxis as per protocol for patients at high risk for CNS relapse during induction and consolidation. Cytospin analysis of the CSF was performed routinely prior to each IT, and no lymphoblasts were seen. In addition, Imatinib mesylate (Novartis Pharmaceuticals, Basel, Switzerland) $600 \mathrm{mg}$ was given simultaneously, courtesy of The Max Foundation (Max Access Solutions ${ }^{\odot}$, The Max Foundation, Seattle, Washington, USA). Packed red cell and platelet transfusions were given as necessary. Induction $1 \mathrm{~A}$ was complicated by neutropenic fever, sepsis and pityriasis versicolor for which he received granulocyte colony stimulating factor (G-CSF), antibiotics (ciprofloxacin, metronidazole), acyclovir, topical clotrimazole and fluconazole. Co-trimoxazole was also given as prophylaxis against Pneumocystis jirovecii. Samples were taken from the two siblings and the parents for human leukocyte antigen (HLA) typing in preparation for allogeneic hemopoietic stem cell transplantation (Allo-HSCT). He achieved remission after induction $1 \mathrm{~A}$ as confirmed by BMA on day 30 . The $B C R-A B L 1$ analysis and flow cytometry could not be repeated due to financial constraints. Induction $2 \mathrm{~A}$ and $2 \mathrm{~B}$ was complicated by the development of multiple subcutaneous abscesses. Microbiological culture yielded methicillin-resistant Staphylococcal aureus. He was treated with meropenem and linezolid. He continued chemotherapy until the consolidation phase when, exactly six months from diagnosis, he developed highgrade fever, headache and vomiting. On admission at the emergency department, he was restless with altered consciousness, fever (temperature $39.4{ }^{\circ} \mathrm{C}$ ), and palor. The Glasgow Coma Scale (GCS) score was 9 out of 15 based on eye opening to pain, utterance of incomprehensible sounds, and localization of pain. The pupils were both $3 \mathrm{~mm}$ in diameter with normal light reactivity. He had neck stiffness and generalized hypertonia, with positive Kernig and Brudzinski signs. Pulse rate was 122 beats per minute; blood pressure was $\frac{144}{70} \mathrm{mmHg}$. A diagnosis of meningoencephalitis with raised intracranial pressure (ICP) was made. The clinical suspicion of raised ICP 
Table 1 Modified MCP 841 Protocol

\begin{tabular}{|c|c|c|}
\hline Phase and duration & Medication & $\begin{array}{l}\text { Dosage } \\
\text { Route and schedule }\end{array}$ \\
\hline \multirow{9}{*}{$\begin{array}{l}\text { Induction } 1 \mathrm{~A} \\
29 \text { days }\end{array}$} & 1. Pre-induction prednisolone & $60 \mathrm{mg} / \mathrm{m}^{2} \mathrm{PO}$ day $1-7$ \\
\hline & 2. Prednisolone & $40 \mathrm{~g} / \mathrm{m}^{2} \mathrm{PO}$ day $8-28$ \\
\hline & 3. Vincristine & $1.4 \mathrm{mg} / \mathrm{m}^{2}$ IV day $8,15,22,29$ \\
\hline & 4. Daunorubicin & $20 \mathrm{mg} / \mathrm{m}^{2}$ IV day $8,15,29$ \\
\hline & 5. L-Asparaginase & $6000 \mathrm{U} / \mathrm{m}^{2} \mathrm{SC}$ day $8,10,12,14,16,18,20,22,24,26$ \\
\hline & 6. CNS prophylaxis: *Triple prophylaxis & \\
\hline & Methotrexate & 12 mg; IT day 8, 15, 22, 29 \\
\hline & Cytarabine & 30 mg; IT day 8, 15, 22, 29 \\
\hline & Hydrocortisone & 20 mg; IT day 8, 15, 22, 29 \\
\hline \multirow{4}{*}{$\begin{array}{l}\text { Induction } 2 \mathrm{~A} \\
28 \text { days }\end{array}$} & Cyclophosphamide & $750 \mathrm{mg} / \mathrm{m}^{2} ; \mathrm{IV}$ day 1,15 \\
\hline & 6-Mercaptopurine & $60 \mathrm{mg} / \mathrm{m}^{2} ; \mathrm{PO}$ day $1-28$ \\
\hline & Cytarabine & 75 mg/m²; IV day 1-4, 8-11, 15-18, 22-25 \\
\hline & CNS prophylaxis as Induction 1A & IT day $8,15,22,29$ \\
\hline \multirow[t]{3}{*}{$\begin{array}{l}\text { Induction 2B } \\
56 \text { days }\end{array}$} & $\begin{array}{l}\text { Cyclophosphamide } \\
\text { 6-Mercaptopurine }\end{array}$ & $\begin{array}{l}750 \mathrm{mg} / \mathrm{m}^{2} ; \text { IV day } 1,15 \\
60 \mathrm{mg} / \mathrm{m}^{2} ; \mathrm{PO} \text { day } 1-56\end{array}$ \\
\hline & Methotrexate & $\begin{array}{l}\text { Low risk: } 20 \mathrm{mg} / \mathrm{m}^{2} \\
\text { IV day } 1,11,21,31,41 \\
\text { High risk: Start at } 100 \mathrm{mg} / \mathrm{m}^{2} \text { and increase by } \\
50 \mathrm{mg} / \mathrm{m} 2 \text { up to } 5 \text { doses }\end{array}$ \\
\hline & CNS prophylaxis as in Induction 1A & IT day $8,15,22,29$ \\
\hline $\begin{array}{l}\text { Induction } 1 \mathrm{~B} \\
28 \text { days }\end{array}$ & Repeat Induction 1A & As in Induction $1 \mathrm{~A}$ \\
\hline \multirow[t]{2}{*}{$\begin{array}{l}\text { Consolidation } \\
28 \text { days }\end{array}$} & $\begin{array}{l}\text { Cytarabine } \\
\text { Vincristine } \\
\text { Cyclophosphamide } \\
\text { Daunorubicin } \\
\text { 6-Mercaptopurine }\end{array}$ & $\begin{array}{l}100 \mathrm{mg} / \mathrm{m}^{2} ; \text { SC 12-hourly day } 1-3,15-17 \\
1.4 \mathrm{mg} / \mathrm{m}^{2} ; \text { IV day } 1,15 \\
750 \mathrm{mg} / \mathrm{m}^{2} ; \text { IV day } 1 \\
20 \mathrm{mg} / \mathrm{m}^{2} ; \text { IV day } 15 \\
75 \mathrm{mg} / \mathrm{m}^{2} ; \text { PO day } 1-7,15-21\end{array}$ \\
\hline & CNS prophylaxis:- Drugs as in Induction 1A & IT day 1 \\
\hline \multirow[t]{2}{*}{$\begin{array}{l}\text { Maintenance } \\
8 \text { cycles for B-ALL ( } 12 \text { weeks per cycle) } \\
96 \text { weeks }\end{array}$} & $\begin{array}{l}\text { Prednisolone } \\
\text { Vincristine } \\
\text { Daunorubicin } \\
\text { L-Asparaginase } \\
\text { 6-Mercaptopurine } \\
\text { Methotrexate }\end{array}$ & $\begin{array}{l}40 \mathrm{~g} / \mathrm{m}^{2} ; \text { PO day } 1-7 \\
1.4 \mathrm{mg} / \mathrm{m}^{2} ; \text { IV day } 1 \\
20 \mathrm{mg} / \mathrm{m}^{2} ; \text { IV day } 1 \\
6000 \mathrm{U} / \mathrm{m}^{2} ; \text { SC day } 1,3,5,7 \\
75 \mathrm{mg} / \mathrm{m}^{2} ; \text { PO daily } \times 12 \text { doses } \\
15 \mathrm{mg} / \mathrm{m}^{2} ; \text { PO weekly }\end{array}$ \\
\hline & CNS prophylaxis:- Methotrexate & 12 mg; IT day 1 of each cycle \\
\hline
\end{tabular}

was based on headache, vomiting, and increased blood pressure that prevented the collection of CSF for cytology and culture. He was placed on intravenous ceftriaxone $2 \mathrm{~g}$ 12-hourly and intravenous dexamethasone $8 \mathrm{mg}$ 8 -hourly, but died within a few hours in the intensive care unit (ICU) while arrangements were being made for cranial computed tomography (CT) scan. The relatives declined autopsy.

\section{Discussion}

The life expectancy of patients with SCA has improved in recent years owing to advances in management that may be associated with the many cases of malignancies now being reported in these patients. In Nigeria, $8.6 \%$ of cases of acute leukemia were associated with sickle cell disease, among which there was only one case of ALL
[2]. Brunson et al. found an increased risk of leukemia in patients with SCD when compared with the general population [12]. The factors associated with this increased risk include chronic inflammation, increased iron levels from frequent transfusions, increased risk of infections, increased erythroid proliferation, and increased bone marrow turnover, which form the pathophysiologic mechanisms of the clinical manifestations of SCD [12]. The index patient presented with typical clinical features of VOC and severe anemia, which occur commonly in patients with SCA. The detection of lymphoblasts in the peripheral blood smear provided the clue to the diagnosis of ALL, which was confirmed by further investigations such as BMA, $B C R-A B L 1$ analysis by PCR, and the immunophenotype. The clinical phenotype of SCA in the patient had been severe with frequent episodes of VOCs 
and blood transfusions, which were said to have become ameliorated in his teenage years. The ECG and echocardiographic findings of LVH were consistent with chronic anemia, which also occurs frequently in patients with SCA [13].

The $B C R-A B L 1$ fusion gene results from the reciprocal translocation between the long arms of chromosomes 9 and 22 , that is, $\mathrm{t}(9 ; 22)(\mathrm{q} 34 ; \mathrm{q} 11)$ [4]. The $A B L 1$ tyrosine kinase gene is transferred from its normal position on chromosome 9 to a new position beside the $B C R$ gene on chromosome 22, resulting in the generation of a novel, highly oncogenic fusion gene $(B C R-A B L 1)$ with a very high constitutive tyrosine kinase activity. This $B C R-A B L 1$ gene is expressed in 95\% of patients with CML, 25-30\% of adult ALL, and $2-3 \%$ of ALL in children $[5,14,15]$. The most common $B C R-A B L 1$ rearrangement in ALL is the e1a2 transcript with a molecular weight of $190 \mathrm{kDa}$ (that is, p190), but the e13a2 (or b2a2) and e14a2 (or b3a2) transcript variants occur less frequently [16]. Other variants such as the e1a3 as reported in this index case are rarely seen in ALL, resulting from the translocation between exon 1 of $B C R$ on chromosome 22 and exon 3 of $A B L 1$ on chromosome 9 [15]. The exon 2 (a2) region of $A B L 1$ that encodes a part of the Src homology (SH) 3 domain is missing from the e1a3 $B C R-A B L 1$ transcript. The role of the SH3 domain in leukemogenesis is controversial. It is a negative regulator of the kinase domain (SH1) of $A B L 1$ and $B C R-A B L 1$ [15]. Therefore, the absence or mutation of the SH3 domain may be associated with a more aggressive form of Ph-positive leukemia due to the loss of its autoinhibitory effect on kinase activity. On the other hand, the $\mathrm{SH} 3$ domain is also required for STAT5 activation by the BCR-ABL1 protein, which is necessary for the expression of its full leukemogenetic effect. In this instance, mutation of $\mathrm{SH} 3$ domain could be associated with a slowly progressive disease. In CML with the e1a3 transcript, the lack of the $\mathrm{SH} 3$ domain was associated with inferior response to Imatinib when compared with the major transcripts and rapid progression to blastic crisis [17]. In other CML patients, the e1a3 transcript was associated with better outcomes $[14,16,18,19]$.

The clinical profile of e1a3 is expected to be similar to that of e1a2 because of their identical molecular weight $(190 \mathrm{kDa})$. However, in CML, the ela2 transcript is associated with monocytosis, extramedullary infiltration, and rapid disease progression similar to chronic myelomonocytic leukemia (CMML) [19].

B-cell acute lymphoblastic leukemia (B-ALL) occurs mainly in children and young adults. The disease is characterized by the expression of B-cell antigens CD19, CD20, or CD22. In most cases, the malignant B lymphocytes are immature (precursor B lymphocytes), while mature lymphocytes are found in only $1-2 \%$ of cases.
This is frequently associated with the expression of various cytogenetic abnormalities that produce fusion genes such as $B C R-A B L 1$ or TEL-AML1 as well as abnormalities in signaling pathway genes such as $R A S, P A X 5$, or PI3K [20]. Philadelphia chromosome-positive ALL is characterized by an aggressive clinical course, poor response to conventional chemotherapy, and poor survival rates [21]. The incorporation of TKIs into the treatment of Ph+ALL is associated with better survival [20, 22]. Imatinib is provided in Nigeria free by The Max Foundation since 2003 through its patient assistance program (Max Access Solutions ${ }^{\odot}$, The Max Foundation, Seattle, Washington, USA). Second-generation TKIs such as Nilotinib or Dasatinib were not available in our center when the patient was managed. Monoclonal antibodies such as rituximab may also be used for therapy [20].

The MCP 841 chemotherapy protocol is a multiagent, multiphase, moderate-intensity regimen that was developed through a collaboration between the Cancer Institute (WIA), Chennai, India and the National Cancer Institute (NCI), Bethesda, USA. It is a standardized treatment protocol that has led to improved survival rates and reduction in treatment-related toxicity among pediatric and adolescent ALL patients treated in resource-poor settings. In the MCP 841 protocol, CNS prophylaxis involves IT alone (in patients younger than 3 years of age) or with cranial irradiation (in patients older than 3 years of age) [10, 11]. Cranial irradiation is effective, but frequently complicated by significant short-term and long-term toxicity, such as, neurocognitive dysfunction, endocrinopathy, secondary neoplasms, and neurotoxicity [23]. Studies have shown that cranial irradiation can be safely omitted from CNS prophylaxis even in high-risk adult or pediatric patients by means of effective systemic chemotherapy and intensive triple intrathecal therapy [24-26]. The protocol modification used in this case involved the replacement of cranial irradiation with the Capizzi escalating-dose systemic methotrexate and triple IT for CNS prophylaxis [26, 27], because there are no facilities for cranial irradiation in our center.

There are relatively few studies on the significance of $B C R-A B L 1$ transcript types in ALL. Some reports have described the presence of the e1a3 transcript in ALL; however, to the best of our knowledge, this is the first report of such in a patient with SCA [28, 29]. In addition, this is the first report from Nigeria in which cytogenetic and immunophenotype analyses were done in the diagnosis of acute leukemia in any patient with SCD. There is limited utilization of cytogenetics and flow cytometry in the diagnostic workup of acute leukemia patients in Nigeria owing to lack of facilities in most centers $[2,3]$.

Fujisawa et al. reported e1a3 transcript in a 25-year old female with precursor B-ALL who presented with 
leukocytosis and thrombocytopenia. Similar to this index case, the patient had chemotherapy and Imatinib therapy simultaneously and achieved complete remission after the first induction cycle. However, the patient succumbed to veno-occlusive disease 18 months from the date of diagnosis [30]. Similarly, Langerbeer et al. reported this rare transcript in a 62-year-old female with Pre-B ALL who also had concomitant chemotherapy with Imatinib therapy. The patient achieved remission with fludarabine, cytarabine, G-CSF, and idarubicin, but relapsed at 18 months and died at 27 months [28]. LopezAndrade et al. reported two patients ALL with the e1a3 $B C R-A B L 1$ ALL transcript. In both patients, the $B C R$ $A B L 1$ transcript remained detectable after induction chemotherapy despite the addition of Imatinib. The first patient achieved complete response by morphology and immunophenotype. The second patient did not respond to treatment based on the presence of lymphoblasts in the post-induction BMA and persistence of $B C R-A B L 1$; he died after second-line induction due to gastrointestinal bleeding [31].

Burmeister et al. of the German Multicenter ALL (GMALL) Study Group detected BCR-ABL1 transcripts in 34\% of 1214 adult B-precursor ALL cases. Eight of these patients had atypical transcripts, five of which were e1a3, two e13a3, and one e6a2 [6].

In all the previously reported cases, the patients died between nine and 27 months unlike this index patient, who died within six months of diagnosis. The shorter duration of survival reported in this case might be due to the associated comorbidities, namely the SCA and meningoencephalitis, which complicated the treatment. Infections are commonly implicated as contributory factors to mortality in ALL patients. In the index patient, an increased risk of severe infection could be linked to impaired cellular and humoral immunity from the cumulative effects of SCA, ALL, and cancer chemotherapy [32].

Nigeria is located within the "meningitis belt" in SubSaharan Africa, and outbreaks of meningitis caused by Streptococcus pneumoniae, Neisseria meningitidis, and Haemophilus influenzae occur frequently [33]. Methicillin-resistant Staphylococcal aureus could also be a cause in the patient considering the history of previous soft-tissue infection caused by the organism in him. In immunocompromised individuals, meningitis could be caused by atypical organisms such as Listeria monocytogenes, Cryptococcus neoformans, Acanthamoeba species, or herpes simplex virus [34]. The other differential diagnoses of meningoencephalitis in the patient include leukemic meningitis, aseptic meningitis, and druginduced meningitis (from IT therapy) [35].
While numerous variant $B C R-A B L 1$ transcripts and their responses to a variety of treatment modalities have been documented in CML $[15,17,36]$. There are fewer reports on these rare variants in Ph+ ALL: the largest series examined to date reveals a total incidence of $1.9 \%$, with the e1a3 transcript type being the most frequently detected at about 1.2\% [6]. All the patients had induction therapy with or without Imatinib. The patients who were treated with Imatinib had better survival after HSCT and less risk of relapse than those who were not treated with Imatinib. The time to HSCT ranged from 100 to 180 days after diagnosis [6]. The index patient died before HSCT could be done on day 180 .

\section{Conclusion}

The occurrence of ALL with the rare e1a3 BCR-ABL1 transcript in SCA is associated with poor prognosis. There is need to develop standardized treatment protocols to improve survival. Stem cell transplantation should be made available to patients as early as possible to improve survival. Routine examination of the peripheral blood film of patients with SCA presenting with features of crises is recommended. Molecular techniques should be included in the diagnostic workup of patients with acute leukemia.

\section{Abbreviations \\ ALL: Acute lymphoblastic leukemia; AML: Acute myeloblastic leukemia; CCR : Complete cytogenetic remission; CD: Cluster of differentiation; CML: Chronic myeloid leukemia; CMML: Chronic myelomonocytic leukemia; CNS: Central nervous system; CSF: Cerebrospinal fluid; ECG: Electrocardiogram; ECHO: Echocardiogram; FAB: French-American-British (classification); FBC: Full blood count; GCS: Glasgow Coma Scale; G-CSF: Granulocyte colony stimulating factor; GMALL: German Multicenter ALL (study group); Hb: Hemoglobin; HIV: Human immunodeficiency virus; HLA: Human leukocyte antigen; HSCT: Hemopoietic stem cell transplantation; ICU: Intensive care unit; ICP: Intracra- nial pressure; IT: Intrathecal therapy; NCl: National Cancer Institute, Bethesda; PCR: Polymerase chain reaction; RBC: Red blood cell; SCA: Sickle cell anemia; SCD: Sickle cell disease; TKI: Tyrosine kinase inhibitor; USA: United States of America; WBC: White blood cell; WIA: Cancer Institute, Chennai, India.}

\section{Acknowledgements}

The authors would like to thank all staff of the Department of Haematology and Blood Transfusion, Obafemi Awolowo University Teaching Hospitals Complex for their assistance and the patient's relatives for their cooperation. The authors acknowledge The Max Foundation for facilitating the free provision of Imatinib to Nigerian patients since 2003.

\section{Authors' contributions}

IOA, LOO, TOO, NOA, and MAD participated in the clinical management of the patient and drafted the manuscript. TOO, NOA, and MAD revised it critically for intellectual content. All authors read and approved the final manuscript.

\section{Funding}

The authors did not receive any funding for this study.

Availability of data and materials

All data generated or analyzed in this study are included in this published article. 


\section{Declarations}

\section{Ethics approval and consent to participate}

Ethical approval was obtained from the Ethics and Research Committee of Obafemi Awolowo University Teaching Hospitals Complex (OAUTHC), Ile-Ife, Nigeria.

\section{Consent for publication}

Written informed consent was obtained from the patient's next-of-kinfor publication of this report and any accompanying images. A copy of the written consent is available for review by the Editor-in-Chief of this journal.

\section{Competing interests}

The authors declare that they have no competing interests.

\section{Author details}

'Department of Haematology and Blood Transfusion, Obafemi Awolowo University Teaching Hospitals Complex (OAUTHC), Ile-Ife, Nigeria. ${ }^{2}$ Department of Haematology and Immunology, Obafemi Awolowo University (OAU), lle-Ife, Nigeria.

Received: 19 May 2021 Accepted: 12 August 2021

Published online: 08 October 2021

\section{References}

1. World Health Organization. Sickle-cell anaemia. Report by the Secretariat. Provisional agenda item 11.4 A59/9. 2006.

2. Aworanti OW, Fasola FA, Kotila TR, Olaniyi JA, Brown BJ. Acute leukemia in sickle cell disease patients in a tertiary health facility in Nigeria: a case series. Afr Health Sci. 2020;20(3):1304-12.

3. Bello-Manga H, Babadoko A, Hassan A, Mamman A, Awwalu S, Adebayo $A$, et al. Acute myeloid leukaemia in a patient with sickle cell disease: a case report and literature review. Arch Med Surg. 2016;1 (1):12-6.

4. Kang Z-J, Liu Y-F, Xu L-Z, Long Z-J, Huang D, Yang Y, et al. The Philadelphia chromosome in leukemogenesis. Chin J Cancer. 2016;35(1):48.

5. Melo J. The diversity of BCR-ABL fusion proteins and their relationship to leukemia phenotype [editorial; comment]. Blood. 1996;88(7):2375-84.

6. Burmeister T, Schwartz S, Taubald A, Jost E, Lipp T, Schneller F, et al. Atypical BCR-ABL mRNA transcripts in adult acute lymphoblastic leukemia. Haematologica. 2007;92(12):1699-702.

7. Baccarani M, lacobucci I, Chiaretti S. Foà'R, Balasubramanian P, Paietta E, et al. In Ph+BCR-ABL1P210+ acute lymphoblastic leukemia the e13a2 (B2A2) transcript is prevalent. Leukemia. 2020;34(3):929-31.

8. Bassan R, Hoelzer D. Modern therapy of acute lymphoblastic leukemia. J Clin Oncol. 2011;29(5):532-43.

9. Durosinmi MA. Haemato-oncology chemotherapy for medical students and doctors. 3rd ed 2013. p. 15-17.

10. Mukhopadhyay A, Gangopadhyay S, Dasgupta S, Paul S, Mukhopadhyay S, Ray UK. Surveillance and expected outcome of acute lymphoblastic leukemia in children and adolescents: an experience from Eastern India. Indian J Med Paediatr Oncol. 2013;34(4):280-2.

11. Pandey A, Ahlawat S, Singh A, Singh S, Murari K, Aryan R. Outcomes and impact of minimal residual disease (MRD) in pediatric, adolescent and young adults (AYA) with acute lymphoblastic leukemia treated with modified MCP 841 protocol. Cancer Res Stat Treatm. 2020;3(2):183-91.

12. Brunson A, Keegan THM, Bang H, Mahajan A, Paulukonis S, Wun T. Increased risk of leukemia among sickle cell disease patients in California. Blood. 2017;130(13):1597-9

13. Dosunmu A, Akinbami A, Uche E, Adediran A, John-Olabode S. Electrocardiographic study in adult homozygous sickle cell disease patients in Lagos Nigeria. J Trop Med. 2016:2016:4214387-92.

14. Roman J, Jimenez A, Barrios M, Castillejo JA, Maldonado J, Torres A. E1A3 as a unique, naturally occurring $B C R-A B L$ transcript in an indolent case of chronic myeloid leukaemia. Br J Haematol. 2001;114(3):635-7.

15. Al-Ali H-K, Leiblein S, Kovacs I, Hennig E, Niederwieser D, Deininger MWN CML with an ela3 BCR-ABL fusion: rare, benign, and a potential diagnostic pitfall. Blood. 2002;100(3):1092-3.
16. Tabassum N, Ghani R, Saboor M, Moinuddin M. Chronic myeloid leukemia with rare e1a3 BCR-ABL transcript. Pakistan J Med Dent. 2015;4:1.

17. Martinez-Serra J, del Campo R, Gutierrez A, Antich JL, Ginard M, Durán MA, et al. Chronic myeloid leukemia with an e1 a3 BCR-ABL fusion protein: transformation to lymphoid blast crisis. Biomarker Res. 2014;2(1):14.

18. Nieborowska-Skorska M, Wasik MA, Slupianek A, Salomoni P, Kitamura T, Calabretta B, et al. Signal transducer and activator of transcription (STAT)5 activation by BCR/ABL is dependent on intact Src homology (SH) 3 and $\mathrm{SH} 2$ domains of $B C R / A B L$ and is required for leukemogenesis. J Exp Med. 1999;189(8):1229-42.

19. Tiribelli M, Tonso A, Ferrero D, Parziale A, Cambrin GR, Scaravaglio P, et al. Lack of SH3 domain does not imply a more severe clinical course in Ph+ chronic myeloid leukemia patients. Blood. 2000;95(12):4019-20.

20. Huang FL, Liao EC, Li CL, Yen CY, Yu SJ. Pathogenesis of pediatric B-cell acute lymphoblastic leukemia: molecular pathways and disease treatments. Oncol Lett. 2020;20(1):448-54.

21. Yilmaz M, Kantarjian H, Ravandi-Kashani F, Short NJ, Jabbour E. Philadelphia chromosome-positive acute lymphoblastic leukemia in adults: current treatments and future perspectives. Clin Adv Hematol Oncol. 2018;16(3):216-23.

22. Tanimura K, Yamasaki K, Okuhiro Y, Hira K, Nitani C, Okada K, et al. Monitoring ponatinib in a child with Philadelphia chromosome-positive acute lymphoblastic leukemia. Case Rep Oncol. 2021;14(1):24-8.

23. Jabbour E, Thomas D, Cortes J, Kantarjian HM, O'Brien S. Central nervous system prophylaxis in adults with acute lymphoblastic leukemia. Cancer. 2010;116(10):2290-300

24. Lin W-Y, Liu H-C, Yeh T-C, Wang L-Y, Liang D-C. Triple intrathecal therapy without cranial irradiation for central nervous system preventive therapy in childhood acute lymphoblastic leukemia. Pediatr Blood Cancer. 2008:50(3):523-7.

25. Muriel FS, Svarch E, Pavlovsky S, Eppinger-Helft M, Braier J, Vergara B, et al. Comparison of central nervous system prophylaxis with cranial radiation and intrathecal methotrexate versus intrathecal methotrexate alone in acute lymphoblastic leukemia. Blood. 1983;62(2):241-50

26. Pui C-H, Campana D, Pei D, Bowman WP, Sandlund JT, Kaste SC, et al. Treating childhood acute lymphoblastic leukemia without cranial irradiation. N Engl J Med. 2009;360(26):2730-41.

27. Winter SS, Devidas M, Chen S, Asselin B, Carroll WL, Wood BL, et al. Capizzi-style methotrexate with pegasparagase (C-MTX) Is superior to high-dose methotrexate (HDMTX) in T-lineage acute lymphoblastic leukemia (T-ALL): results from Children's Oncology Group (COG) AALL0434. Blood. 2015:126(23):794-794.

28. Langabeer SE, Haslam K, Kelly J, Leahy M, Vandenberghe E. Acute lymphoblastic leukaemia with an e1a3 <i>BCR-ABL1</i> fusion. Acta Haematol. 2011;126(4):214-5.

29. Shin SY, Cho JH, Kim HJ, Jang JH, Lee ST, Kim SH. Two cases of acute lymphoblastic leukemia with an e1a3 BCR-ABL1 fusion transcript. Ann Lab Med. 2015;35(1):159-61.

30. Fujisawa S, Nakamura S, Naito K, Kobayashi M, Ohnishi K. A variant transcript, e1 a3, of the minor BCR-ABL fusion gene in acute lymphoblastic leukemia: case report and review of the literature. Int J Hematol. 2008:87(2):184-8

31. López-Andrade B, Sartori F, Gutiérrez A, García L, Cunill V, Durán MA et al. Acute lymphoblastic leukemia with e1a3 BCR/ABL fusion protein. A report of two cases. Exp Hematol Oncol. 2015;5:21.

32. Malhotra P, Chauhan S, Bhatt P, Varma N, Chakrabarti A, Kumari S, et al. Cryptococcal meningitis in acute lymphoblastic leukemia. J Assoc Phys India. 2004:52:831-2.

33. Tagbo BN, Bancroft RE, Fajolu I, Abdulkadir MB, Bashir MF, Okunola OP, et al. Pediatric bacterial meningitis surveillance in Nigeria from 2010 to 2016, prior to and during the phased introduction of the 10-valent pneumococcal conjugate vaccine. Clin Infect Dis. 2019;69(Supplement_2):S81-8.

34. Castro I, Ruiz J, Tasias M, Montero M, Salavert M. Central nervous system infections in immunocompromised patients. Revista espanola de quimioterapia : publicacion oficial de la Sociedad Espanola de Quimioterapia. 2018;31(Suppl 1):56-61.

35. Beaumont A-L, Suner L. Drug-induced aseptic meningitis in a Ph+ ALL patient with meningeal involvement. Blood. 2020;136(4):520-520. 
36. Kantarjian HM, Talpaz M, Giles F, O'Brien S, Cortes J. New insights into the pathophysiology of chronic myeloid leukemia and imatinib resistance. Ann Intern Med. 2006;145(12):913-23.

\section{Publisher's Note}

Springer Nature remains neutral with regard to jurisdictional claims in published maps and institutional affiliations.

- fast, convenient online submission

- thorough peer review by experienced researchers in your field

- rapid publication on acceptance

- support for research data, including large and complex data types

- gold Open Access which fosters wider collaboration and increased citations

- maximum visibility for your research: over $100 \mathrm{M}$ website views per year

At BMC, research is always in progress.

Learn more biomedcentral.com/submissions 